
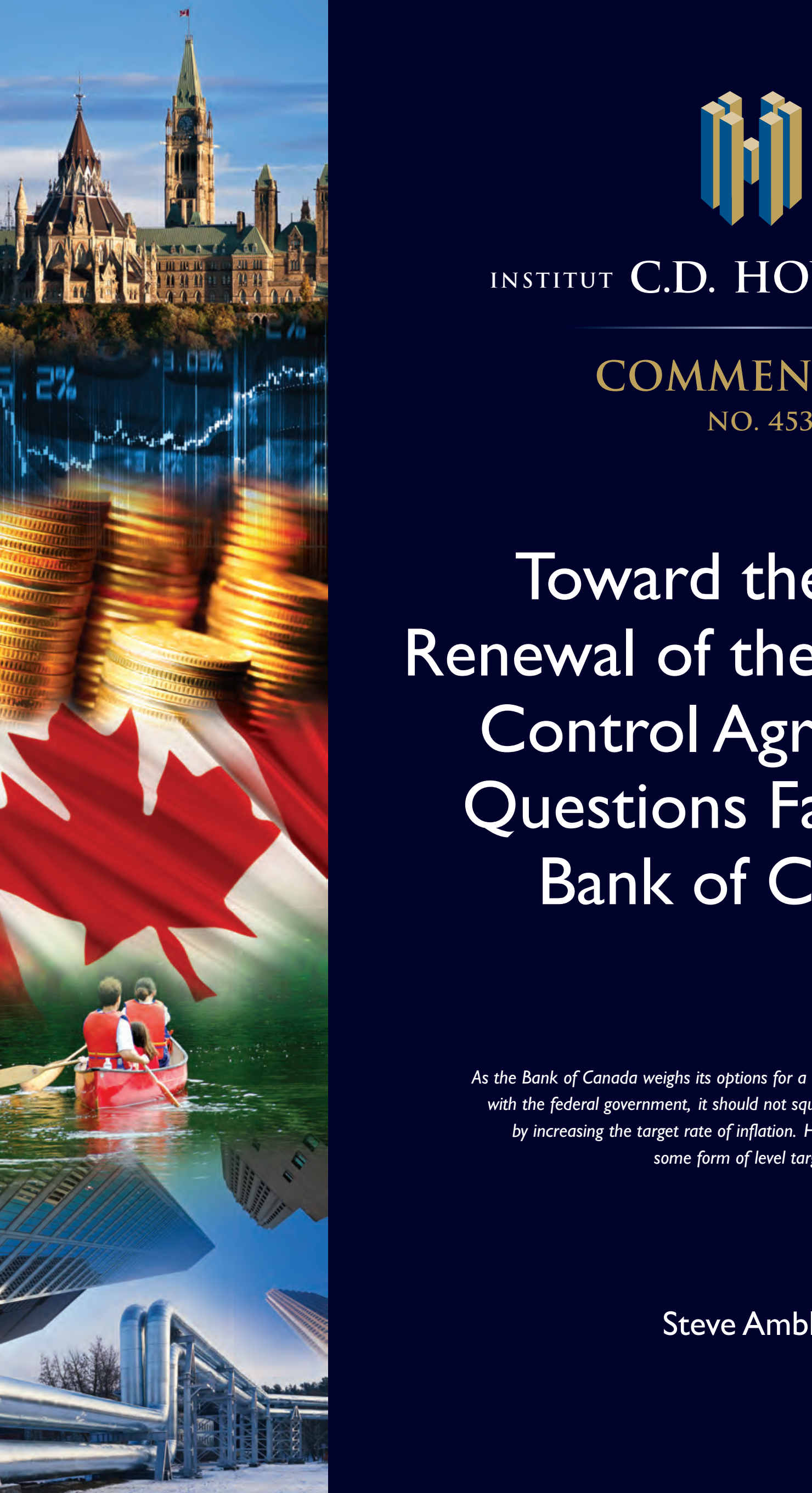

\section{institut C.D. HOWE institute}

\author{
COMMENTARY
}

NO. 453

\title{
Toward the Next Renewal of the Inflation- Control Agreement: Questions Facing the Bank of Canada
}

As the Bank of Canada weighs its options for a new inflation-control agreement with the federal government, it should not squander its hard-won credibility by increasing the target rate of inflation. However, it should consider some form of level targeting. 


\section{THE INSTITUTE'S COMMITMENT TO QUALITY}

\section{ABOUT THE AUTHOR}

Steve Ambler is the David Dodge Chair in Monetary Policy at the C.D. Howe Institute, professor in the Economics Department at the Université du Québec à Montréal, senior fellow of the Rimini Centre for Economic Analysis, and a member of the Inter-University Centre on Risk, Economic Policies and Employment (CIRPEE).

Commentary No. 453

June 2016

Monetary Policy
C.D. Howe Institute publications undergo rigorous external review by academics and independent experts drawn from the public and private sectors. The Institute's peer review ensures the quality, integrity and objectivity of its policy research. The Institute will not publish any study that, in its view, fails to meet these standards.

The Institute requires that its authors publicly disclose any actual or potential conflicts of interest of which they are aware.

In its mission to educate and foster debate on essential public policy issues, the C.D. Howe Institute provides nonpartisan policy advice to interested parties on a non-exclusive basis. The Institute will not endorse any political party, elected official, candidate for elected office, or interest group.

As a registered Canadian charity, the C.D. Howe Institute as a matter of course accepts donations from individuals, private and public organizations, charitable foundations and others, by way of general and project support. The Institute will not accept any donation that stipulates a predetermined result or policy stance or otherwise inhibits its independence, or that of its staff and authors, in pursuing scholarly activities or disseminating research results.
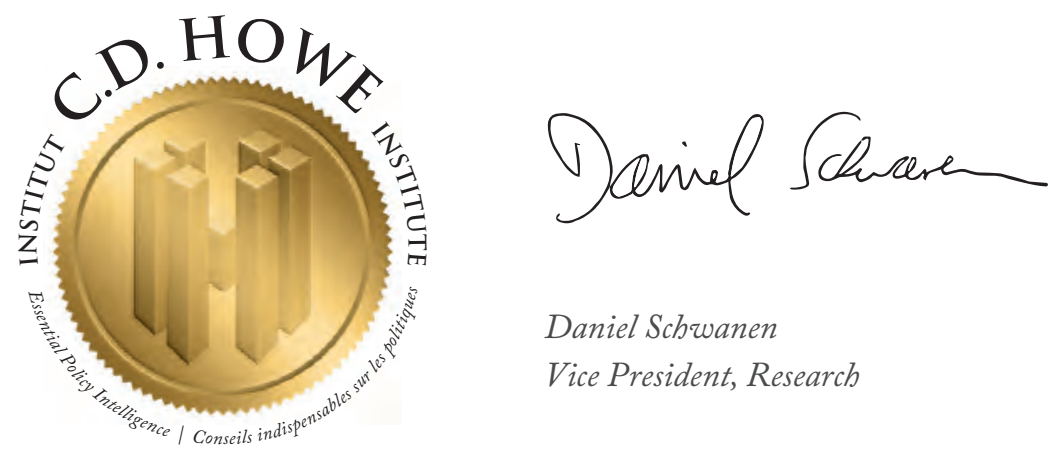

Daniel Schwanen

Vice President, Research 


\section{THE STUDY IN BRIEF}

With the Bank of Canada set to renew its inflation-control target agreement with the federal government later in 2016, this paper investigates three directly related questions:

- Should the targeted rate of inflation be raised above 2 percent?

- How should considerations of financial stability be integrated with monetary policy?

- What should the Bank use as its measure of core inflation?

As for the first question, this paper argues that the Bank of Canada should not squander its hard-won credibility by increasing the target rate of inflation, especially since the costs of even moderate trend inflation (in the range of 3-4 percent) might be higher than previously estimated. Given worries about the zero lower bound, the Bank should consider alternative monetary policy frameworks, including some form of level targeting. The rapid adjustment in expectations to the inflation-targeting regime in 1991 should allay the Bank's fears concerning its communication and how quickly the public would adapt to a new policy framework.

Concerning financial stability policy, the Bank of Canada should refine and extend its guidelines for extending liquidity to financial markets. In particular, it should consider under what limited circumstances it would extend credit bilaterally to individual financial institutions while still favouring a market-based allocation mechanism. It should also consider if and under what circumstances it would intervene in frozen markets for particular asset classes by acting as market maker of last resort. In addition, macroprudential policy should concentrate on simple heuristic strategies based on the principle of "skin in the game."To the extent that macroprudential policy involves nonmarket control over the allocation of resources, it would be better for the Bank to participate as one of several experts in an independent body tasked to promote financial stability. Otherwise, it would leave itself open to criticism for a lack of accountability and thereby risk jeopardizing its operational independence. The independent body should be directly responsible to the Department of Finance.

Strong arguments exist for actually targeting a core-like measure of inflation in which components of the index are weighted by their degree of stickiness. Targeting such an index could lead to increased economic welfare by making monetary policy more effective, even if it is overall headline inflation that is costly to households. Although it might not be feasible to coordinate on such an index in time for the 2016 agreement, the Bank should prepare to move to target a different index in the medium term.

C.D. Howe Institute Commentary $($ is a periodic analysis of, and commentary on, current public policy issues. Barry Norris and James Fleming edited the manuscript; Yang Zhao prepared it for publication. As with all Institute publications, the views expressed here are those of the author and do not necessarily reflect the opinions of the Institute's members or Board of Directors. Quotation with appropriate credit is permissible.

To order this publication please contact: the C.D. Howe Institute, 67 Yonge St., Suite 300, Toronto, Ontario M5E 1J8. The full text of this publication is also available on the Institute's website at www.cdhowe.org. 


\section{Canada has had an inflation-targeting regime since 1991, with a target of 2 percent since 1995 and a control range of 1-3 percent.}

The Bank of Canada periodically renews its agreement with the federal government concerning the inflation-control target. The last renewal, signed in 2011, is set to expire in December 2016. Since 1996, the main components of this inflation-control target have remained the same.

A substantial part of the Bank's research agenda is devoted to analyzing how well its monetary policy framework is performing and whether it should be either tweaked or modified substantially. In a 2014 speech, Deputy Governor Agathe Côté (2014) summarized the three main questions the Bank is looking at before the 2016 renewal, as well as the results of research conducted before the 2011 renewal as set out in the Bank's background document to that renewal (Bank of Canada 2011). The three questions are as follows:

- Should the targeted rate of inflation be raised above 2 percent?

- How should considerations of financial stability be integrated with monetary policy?

- What should the Bank use as its measure of core inflation?

In this Commentary, I review some of the issues related to these three questions to which the Bank should pay careful attention. Following from this analysis, I argue that the Bank should

1. avoid squandering its hard-won credibility by increasing the inflation target;

2. consider modifications to the monetary policy framework up to and including some form of level targeting;
3. refine and expand its guidelines for liquidity provision in times of crisis;

4. seek simple heuristic approaches to promote financial stability;

5. continue to mitigate the risks of moral hazard;

6. avoid taking on direct responsibilities vis-à-vis financial stability that have significant allocative or distributional consequences;

7. reserve the overnight rate to target monetary policy objectives; and

8. consider targeting a price index that gives a low weight to volatile and non-sticky components, rather than just using such an index as a predictor of movements of overall headline inflation.

\section{A Change in The TARgeted RATE}

Before the 2008-09 Great Recession and the last renewal of its inflation-targeting regime in 2011, the Bank of Canada was seriously considering lowering the inflation target below 2 percent. This would have been a move toward true price stability, and might have reduced the economic costs associated with inflation. ${ }^{1}$ The context was a period during which the Bank was, on average, successful in hitting its inflation target and fluctuations in output were relatively mild. Between the beginning of 1996 (around the time inflation dipped below 2 percent) and the end of 2006 (just after the 2006 renewal), inflation averaged 2.03 percent.

The author thanks Jeremy Kronick, Mati Dubrovinsky, Finn Poschmann, Edward A. Carmichael, Pierre Duguay, Paul Jenkins, David Laidler, David Longworth, Michael Parkin, Pierre Siklos, David R. Johnson and John D. Murray for helpful comments; the author retains responsibility for any errors and the views expressed.

1 See Ambler (2008) for a review of the costs of inflation in modern macroeconomic theory. 
The financial crisis of 2007-08 and the onset of the Great Recession led the Bank of Canada, along with many other major central banks, to lower its policy rate to its assumed lower bound. At the time, the Bank considered the overnight rate of 25 basis points to be its effective lower bound for operational reasons. It has since entertained the possibility of a negative overnight rate (Poloz 2015b), and central banks such as the European Central Bank have actually implemented negative policy rates. There are still limits, however, on how low a central bank's policy rate can go before banks and other individuals switch to holding cash, which yields a nominal interest rate of zero (except for the insurance and storage costs involved in holding it). Once the lower bound has been reached, there is no room left for conventional monetary policy to be more expansionary.

The Bank of Canada's overnight rate remained at 25 basis points between April 2009 and May 2010 , but the policy rates of some other major central banks stayed at their lower bound for much longer - for example, the US Federal Reserve's policy rate remained at 25 basis points from December 2008 until December 2015. Moreover, many central banks have been systematically undershooting their inflation targets. In Canada, inflation averaged 1.90 percent from the beginning of 2007 to the end of 2011 (just after the announcement of the last renewal), and 1.37 percent from the beginning of 2012 until the end of 2015, while real output remained significantly below its pre-2008 trend level. ${ }^{2}$
Analysts and central banks largely failed to anticipate the financial crisis that triggered the Great Recession. Policies are now being considered to prevent a recurrence of the crisis, but most central banks have revised upwards their evaluation of the probability of their policy rates hitting the zero lower bound. It also seems likely that the long-run neutral rate of interest (the rate of interest compatible with full employment and a rate of inflation equal to the target) in Canada (and elsewhere) is lower because of slower real growth and demographic factors. ${ }^{3}$ If this is so, some studies - such as Blanchard, Dell'Ariccia and Mauro (2010) and Bayoumi et al. (2014) - have suggested that a higher inflation target could be beneficial by reducing the probability that a negative shock will push policy rates to their lower bound. The Bank of Canada seems to be seriously contemplating this possibility. It should resist the temptation, however, for a number of reasons. ${ }^{4}$

\section{Distributional Consequences and Loss of Credibility}

First, an increase in the targeted rate of inflation would cause a transfer of wealth from creditors and savers to debtors. Holders of bonds with principals fixed in nominal terms would suffer capital losses. It would also reduce the wealth of individuals whose incomes are fixed in nominal terms and not completely indexed to the cost of living, thereby affecting many pensioners with defined-benefit plans. This is precisely the kind of unanticipated

2 There are many possible explanations for this, including a weak global recovery from the Great Recession, weak energy price inflation, continued slack in the Canadian economy and increased competition in the retail sector. See Macklem (2014) for a summary of the arguments and the evidence.

3 See Wilkins (2014) and Ambler and Alexander (2015) for summaries of some of the arguments.

4 An additional argument for raising the inflation target is that it might alleviate the effects of possible downward nominal wage rigidity by reducing the frequency that downward wage adjustment is necessary to foster labour market equilibrium. See Kryvtsov and Mendes (2015) for a summary of this argument. 
redistribution of wealth that the inflation-targeting regime was intended to avoid by making inflation more predictable. If the inflation target were to be raised with little warning, it would constitute a breach of trust and could seriously undermine the Bank of Canada's credibility. An inflationtargeting regime does not allow individuals to predict future prices with certainty: shocks to inflation are not corrected, and therefore can have a permanent effect on the level of prices. In practice, however, Canada's inflation-targeting regime has kept average inflation very close to the 2 percent target since 1996, conferring a relatively high degree of predictability to future prices and reducing uncertainty for parties to contracts whose payoffs are denominated in nominal terms (such as almost all mortgages). ${ }^{5}$ Any change to the target rate, of course, would be the joint decision of the Bank and the federal government. Because of the implied fiscal consequences, the need to explain and justify the distributional implications of an increase in the target should be an important part of the negotiations with the government concerning the renewal, and ought to feature prominently when the Bank releases its background document explaining the renewal.

If the Bank of Canada were to raise the targeted rate of inflation, it is not clear that expectations would coalesce quickly (or at all) around the higher target. Markets could well incorporate an expectation of further future increases in the target, which would mean a loss of credibility for the Bank. In turn, this could decrease the effectiveness of changes in the policy rate to influence aggregate demand and keep inflation on track. If inflation expectations became unanchored from the target, future negative shocks might require larger reductions in the overnight rate to move inflation back to the target. This would defeat the purpose of moving the neutral rate of interest farther from the zero lower bound.

\section{The Potential Welfare Costs of Even Moderate Trend Inflation}

The second reason the Bank of Canada should resist raising the inflation target is that it may be costly in terms of economic welfare. Advocates of a higher target argue that inflation is not very costly at moderate rates - say two or three percentage points higher than the current 2 percent target. These arguments may depend critically on the type of economic model used to do the welfare calculations that lead to this conclusion. In a recent study of the US economy, Ascari, Phaneuf and Sims (2015) use a model that extends the standard New Keynesian model in several plausible directions. First, it includes multi-period nominal wage rigidities. Second, it embodies trend growth in neutral and investment-specific productivity. Third, it takes into account the roundabout nature of the production structure of advanced economies, with the outputs of most sectors being used as inputs by almost all other sectors. The authors calculate that an increase in trend inflation from 2 to 4 percent would lead to a total welfare loss equivalent to 6.9 percent of one year's average level of consumption. This is an order of magnitude higher than the welfare loss of higher inflation in models without these plausible modifications. ${ }^{6}$ The persistent effects of shocks to

5 As noted earlier, inflation has started to undershoot the target systematically since the Great Recession.

6 This includes the Bank of Canada's own principal forecasting model, ToTEM, which takes account of the roundabout nature of production in a very limited way. For this reason, it would also understate the costs of moderate inflation in the Canadian economy. The authors' extensions are features of all advanced economies, including Canada's. Relying on the predictions of a simulated model can be justified by noting that no central bank that has adopted an explicit inflation target has subsequently increased the targeted rate of inflation. 
the marginal efficiency of investment are responsible for a large fraction of the economic costs in their model.

This would suggest that moderate trend inflation might well be much more costly than previously thought. If, as Blanchard, Dell'Arricia and Mauro (2010) argue, increasing the targeted rate decreases the frequency with which the policy rate is driven to its lower bound, the Bank of Canada should look for better alternatives. As I argue below, level targeting is one alternative that makes hitting the lower bound less likely.

\section{Inflation Targeting and Multiple Equilibria}

Even with a higher target for inflation, an inflationtargeting regime is potentially fragile because of the so-called multiple equilibria problem. Benhabib, Schmitt-Grohé and Uribe (2001a, 2001b) show that, in any general equilibrium model with sticky prices, when the central bank sets a short-term nominal rate of interest to achieve an inflation target, there must always be two long-term equilibria for the economy. The equilibria share the same real interest rate, determined by households' degree of impatience in accordance with standard macroeconomic theory. In both equilibria, the nominal interest rate equals the real interest rate plus the trend rate of inflation.

In the "good" equilibrium, inflation is equal to its target and output is equal to its full-employment level. The "bad" equilibrium involves a short-term nominal interest rate of zero, which means that inflation must be negative to satisfy the equilibrium relationship between the nominal interest rate and the real interest rate. Inflation has no tendency to increase from this negative rate because there is a large negative output gap. Output is well below its full-employment level, and so firms have no incentive to increase the price of their output.

The results of Benhabib, Schmitt-Grohé and Uribe are more than just theoretical. Bullard (2010) contends that Japan's experience with low inflation or deflation in the first decade of the millennium indicates that it has been stuck close to this bad equilibrium for some time.

Furthermore, when the nominal interest rate is close to zero, central bank policy cannot react strongly to negative shocks to inflation because of the lower bound constraint. The bank's policy does not satisfy the Taylor principle, which states that the policy rate must react by more than variations in the inflation rate to guarantee that monetary policy is stabilizing. If the policy rate reacts by less than changes in inflation, the real interest rate can move in the wrong direction if expected inflation does not diverge too much from realized inflation.

For example, a negative inflation shock would lead to an increase in the real interest rate, which would depress aggregate demand and lead to further downward pressure on the inflation rate. If the Taylor principle is not satisfied, the economy might be pulled toward the "bad" equilibrium with a zero interest rate and depressed output. Evans, Guse and Honkapohja (2008) show that it is not necessary for a negative shock to push the nominal interest rate to zero. All that is required is that the shock push it low enough so that the economy is then pulled toward the bad equilibrium with a zero rate. This could occur even with a higher target rate, and the threshold below which the economy would be pulled toward the bad equilibrium is highly uncertain.

\section{Unconventional Monetary Policies at the Zero Lower Bound}

Côté (2014) notes that the Bank of Canada is studying so-called "unconventional monetary policies"(UMPs) and how they can help the economy avoid and get out of zero-lower-bound situations. These policies include things such as forward guidance and quantitative easing (for surveys, see Kozicki, Santor and Suchanek 2011; and Santor and Suchanek 2013). She notes, "it is still unclear to what extent UMPs can effectively substitute for conventional monetary policy." 
It is possible that the most effective unconventional monetary policies involve level targeting of some kind. Price-level targeting involves fixing a target path for the consumer price index (CPI) itself (or another price index). It has been shown to lead, at least in the context of simulation models, ${ }^{7}$ to greater stability of both inflation and real output. With lower inflation variability, the central bank's policy rate is less likely to be driven to its lower bound by an unfavourable shock. Also, if the policy rate is at the lower bound, inflation over the medium to long term will be expected to be equal to the targeted trend inflation rate, so that the real ex ante interest rate at those horizons will in general be more negative than under inflation targeting, providing more stimulus to the economy. ${ }^{8}$ This follows from simple arithmetic: for a given level of the nominal interest rate, a higher expected rate of inflation means a lower ex ante real interest rate.

Credibility is important. This means that any price-level targeting regime must be symmetric, which in turn, means that correcting positive surprises to inflation is as important as correcting negative surprises to inflation, or credibility will be lost. If the positive inflation surprise is due to a positive aggregate demand shock, a period of inflation that is lower than the target is compatible with reducing the size of the (positive) output gap. If it is due to a supply shock such as an increase in oil prices, there is a strong argument that the central bank should not cause a decrease in demand to bring the overall CPI back to its target path. It should, in fact, target a price index other than the CPI, as I discuss below.

The Bank of Canada's main objection to forms of level targeting seems to be that such policies work well only if they are well understood by the public and if the public is able to forecast the effects of monetary policy under these changed regimes (see Côté 2014). Recall that the initial implementation of inflation targeting in 1991 was to a large extent a leap of faith. Its success depended on credibility and on rapid learning by individuals to allow for convergence of medium-term inflation expectations to the target and a moderation of wage settlements in what was, up to 1991, a high-inflation environment. The decrease in inflation between 1991 and 1996 was more rapid and less painful than some (including at the Bank) had predicted. ${ }^{9}$

The current context is different. Instead of looking for a regime that can bring high inflation under control, Canada and other advanced economies are currently faced with looking for adjustments to monetary policy that will help fend off either outright deflation or inflation that is persistently below their targets. Many analysts attribute the stagnant growth of the world economy to the seeming inability of central banks to stimulate the growth of aggregate demand. This should serve to concentrate the minds of central bankers and encourage them to try innovative approaches such as level targeting. The economic costs of stagnant growth might well be comparable

7 Empirical evidence on price-level targeting is limited since it has only been tried for a period of a few years in Sweden in the 1930s; see Berg and Jonung (1999) for a detailed discussion.

8 See Amano and Ambler (2014) for a simulation study supporting these conclusions. They show that a price-level-targeting regime involves both fewer episodes at the zero lower bound and shorter episodes; see also Amano and Shukayev (2010, 2012). Coibion, Gorodnichenko and Wieland (2012) find that the optimal trend inflation rate under price-level targeting is closer to zero than under inflation targeting, and that moving from inflation targeting to price-level targeting yields substantial gains in economic welfare.

9 Amano, Engel-Warnick and Shukayev (2011) present evidence from laboratory experiments showing that subjects adapt relatively quickly to a price-level-targeting regime, although they do not fully use the target-reverting nature of the price level when forecasting inflation. 
to the costs of high inflation in the 1980s, which led to the last major shift in the monetary policy frameworks central banks use.

Level targeting has another important advantage: it eliminates the problem of multiple long-term equilibria under inflation targeting. Ambler and Lam (2015) show that a credible price-level-targeting regime can have only one long-run equilibrium, with inflation equal to its targeted trend rate and output close to its full-employment level.

\section{Simple Alternatives}

Without going all the way to level targeting, simple alternatives are also available. One such alternative would be average-inflation targeting (see, for example, Nessén and Vestin 2005). Under average-inflation targeting, instead of targeting the rate of inflation itself, the central bank would target a moving average of past inflation rates. In fact, Canada's current inflation-targeting regime is already a form of average-inflation targeting. Inflation figures are published monthly, and headline inflation is defined as year-on-year inflation, which is just the moving average of monthly inflation rates over the past twelve months or the past four quarters.

The main reason for adopting average-inflation targeting is to ensure that the central bank corrects past deviations of inflation targeting to some extent. If inflation as measured by the moving average is lower than the targeted rate, then to bring the moving average back to target, monthly or quarterly inflation would have to move higher than the targeted rate in the short run.

Correcting past deviations of inflation means that bygones are not bygones, as they are under a pure inflation-targeting regime. The central bank's policy becomes history dependent, a hallmark not only of level targeting but also of policy under commitment in the sense of Kydland and Prescott (1977), ${ }^{10}$ and therefore a means of attaining a higher level of economic welfare (see also Dennis 2003; and Dennis and Söderstöm 2006). As the length of the moving average window increases, so does the amount by which the central bank has to correct for past deviations of inflation from the target. Nessén and Vestin (2005) show that, in the limit, as the moving average becomes very long, an average-inflation-targeting regime approaches a price-level-targeting regime.

Moving to a two-year-on-two-year (or even a longer) period would be a way to move in the direction of price-level targeting with minimal changes to the policy framework. At or close to the zero lower bound, it would have the advantage of increasing inflation expectations going forward, lowering real interest rates and, thereby, stimulating aggregate demand.

\section{The Bottom Line}

The Bank of Canada should not squander its hardwon credibility by increasing the target rate of inflation, especially since the costs of even moderate trend inflation (in the range of 3-4 percent) might be higher than previously estimated. Given worries about the zero lower bound, the Bank should consider alternative monetary policy frameworks, including some form of level targeting. The rapid adjustment of expectations to the inflationtargeting regime in 1991 should allay the Bank's fears concerning its communications and how quickly the public would adapt to a new policy

10 They showed in their seminal paper that the strategy of committing to an announced policy path leads to improved economic welfare. Such strategies have the property that they depend on the past as well as on the current state of the economy. 
framework. Level targeting would also help Canada avoid falling into a low-inflation, low-output trap of the kind that has plagued Japan and that might now have infected the euro zone. If the Bank is completely averse to level targeting, simple alternatives such as average inflation targeting are available and would entail only small adjustments to the current monetary policy framework.

\section{FINANCIAL STABILITY}

Côté (2014) refers to the question of the integration of considerations of financial stability with monetary policy as "a work in progress," noting that the low-interest-rate policies of many central banks in recent years have led to concerns of pressure building up in financial markets.

According to Buiter (2012), financial stability policy should prevent or mitigate: (i) asset market and credit booms, bubbles and busts; (ii) liquidity crises for systemically important financial institutions and for the sovereign - that is, the central bank should act as lender of last resort; (iii) market liquidity crises for systemically important instruments by the central bank's acting as market maker of last resort; and (iv) solvency crises for systemically important financial institutions.

\section{Lender and Market Maker of Last Resort}

The second role of financial stability policy - to prevent or mitigate liquidity crises for systemically important financial institutions and to act as lender of last resort - has been a traditional part of central banking since the nineteenth century and should continue to be so. ${ }^{11}$ Bagehot ([1873] 1999) is the standard source for how central banks should act as lender of last resort. Humphrey (1989) summarizes Bagehot's principles as follows: ${ }^{12}$

- protect the money stock instead of saving individual institutions;

- rescue only solvent institutions;

- let insolvent institutions default;

- charge penalty rates;

- require good collateral; and

- pre-announce these conditions before a crisis so that the market knows exactly what to expect.

The third role of financial stability policy - acting as market maker of last resort or, in the parlance of Mehrling (2014), dealer of last resort - is similar to that of lender of last resort. This role, however, only came into play in full force during the 2007-08 financial crisis, when the interbank market (involving both traditional and nonbank financial intermediaries or "shadow banks") for short-term funding seized up completely. Rather than extending credit, acting as market maker of last resort involves purchasing assets in markets where liquidity has dried up. Tucker $(2015,29)$ relates the two functions as follows: "just as by lending the [lender of last resort] can signal that the beneficiary(ies) is in fact OK, so by purchasing securities they could signal that fears about an asset class were misplaced." Tucker goes on to discuss how principles similar to Bagehot's can be applied to the role in this case.

11 Tucker (2015) argues that, even if liquidity should be provided to financial institutions primarily by providing to the market as a whole, there will remain a need in limited cases for direct, bilateral assistance.

12 Much of what Bagehot wrote has been interpreted in different ways by different scholars. I rely on Humphrey's interpretations, which are not without controversy. See also Bordo (2014); Haltom and Lacker (2014a); Hogan, Le and Salter (2015); and Laidler (2003) for further and possibly differing interpretations, and Mehrling (2011, 2014) for an analysis of how Bagehot's prescriptions can and should be modified to suit the current institutional context. 
During the financial crisis, the US Federal Reserve acted frequently as both lender and market maker of last resort, undertaking transactions involving both direct bilateral relationships with banks and other institutions and more marketbased allocation mechanisms such as auctions. Cochrane (2009), Hummel (2011), Humphrey (2010), White (2010) and others have argued that Bagehot's principles have been honoured more in the breach than in the observance by central banks such as the Fed. They argue that the Fed has used its powers to allocate credit to specific sectors and institutions and to rescue insolvent financial institutions using the justification of systemic importance. In other words, the Fed has engaged in "credit policy," rather than in monetary policy. With these competing views in mind, how might central banks act so as to follow Bagehot's principles and still act as market maker of last resort when necessary?

\section{Credit Policy}

Acting as lender or market maker of last resort and mitigating solvency crises for systemically important institutions embodies the danger that central banks' responsibilities would be greatly enlarged, and that they would come to make decisions concerning the allocation of credit to individual sectors and individual financial firms.

Goodfriend $(2014,113)$ defines the distinction between monetary and credit policy as follows: "Monetary policy refers to the expansion or contraction of currency or bank reserves via Fed purchases or sales of Treasury securities." It is true that even pure monetary policy has consequences for a government's budget constraints, since the central bank remits any profits (less its operating costs) from its holdings of treasury securities to the government. These consequences are relatively circumscribed, however, and by holding treasury securities in order to expand and contract the monetary base, the central bank avoids credit risk, at least insofar as the risk of sovereign default is zero or exceedingly low.

Goodfriend notes that "[c]redit policy involves lending to financial institutions or the purchase of non-Treasury securities financed by selling Treasury securities." Such actions involve taking on credit risk, and fall into the realm of fiscal policy. Goodfriend further says that, "[w] hen consolidated with the Treasury's balance sheet, Fed credit policy contributes loans and purchases of non-Treasury securities. Unlike monetary policy, Fed credit policy involves fiscal policy - lending to particular borrowers - financed by sales of Treasuries against future taxes" $(2014,113)$.

Fiscal policy is usually undertaken by elected officials who are accountable at least to the electorate. Making the Bank of Canada responsible for such decisions could lead to conflict with the Department of Finance and to increased scrutiny by the press and other outside critics of the Bank. In turn, this could eventually threaten the Bank's effective operational independence. As Goodfriend $(2014,116)$ notes:

A Fed credit policy decision that commits substantial taxpayer resources in support of the financial system or one that denies taxpayer resources is inherently a highly-charged, political, fiscal policy matter. Initiatives that extend the Fed's credit reach in scale, maturity, and eligible collateral to unsupervised or potentially insolvent institutions inevitably carry credit risk, excite questions of fairness, and potentially threaten conflict between the Fed and the fiscal authorities - with the potential to destabilize financial markets and employment. Worse, an ambiguous boundary of expansive Fed credit policy creates expectations of Fed accommodation in financial crises, which blunt the incentive of private entities to take preventive measures beforehand to shrink their counterparty risk and reliance on short-term finance, and build up financial capital.

The "expectations of Fed accommodation" to which Goodfriend alludes amount to the problem of 
moral hazard. A bank that knows it is systemically important also knows that the central bank will intervene to mitigate any potential solvency crisis. This, in turn, will influence the kinds of risks the bank is willing to take on. Indeed, many authors for example, Cochrane (2009); Haltom and Lacker (2014b); Humphrey (2010); Roberts (2010); and White (2010) - have argued that moral hazard was at the centre of the 2007-08 financial crisis.

\section{The Bank of Canada's Intervention in Financial Markets}

The Bank of Canada's intervention in financial markets in 2008-09 was relatively circumscribed. To provide liquidity to financial markets, the Bank set up its "term Purchase and Resale Agreement" (PRA), which offered short-term collateralized funds to participants in the Large Value Transfer System ${ }^{13}$ that were undergoing difficulties obtaining short-term financing in private markets. The program was initiated in December 2007 and was wound down in 2009. At the time, the Bank was acutely aware of the potential problems posed by taking on credit risk and by the creation of moral hazard. The facility was based on auctions, so it acted as lender of last resort, and its credit was allocated via auctions, rather than through direct bilateral relationships with financial institutions. The manifestation of the financial crisis in Canada was the freeze-up of the market for asset-backed commercial paper, which the Bank allowed to be used as collateral when providing liquidity through the PRA facility, but it did not itself make outright purchases of such commercial paper.
To tie its own hands, the Bank laid down a specific set of guidelines for the use of the term PRA facility. Under these guidelines, first outlined in Engert, Selody and Wilkins (2008) - which indicates they were developed during the heat of the financial crisis - and summarized in Longworth (2010) and Selody and Wilkins (2010), intervention was to be:

- targeted to mitigating market failures of systemwide importance that a central bank could rectify by providing liquidity;

- graduated or commensurate with the severity of the problem;

- well designed and based as much as possible on market-based transactions via auctions, while loans could be used to address liquidity shortages affecting specific institutions;

- at market-determined prices to minimize distortions and to prevent the crowding out of market transactions by the central bank; and

- designed to limit potential problems of moral hazard by being limited, selective and at penalty rates as appropriate.

These guidelines show that the Bank was well aware of its own limitations and of the dangers of interfering with market equilibrium. ${ }^{14}$ This is appropriate. The Bank should retain this set of principles to govern its intervention in financial markets and work on further refining their details.

\section{Macroprudential Policy}

Buiter's (2012) first and fourth roles for financial stability policy - preventing or mitigating asset market and credit booms bubbles and busts,

13 This is an electronic system, launched in 1999, that lets financial institutions and their customers send large payments securely in real time. See http://www.bankofcanada.ca/core-functions/monetary-policy/lvts/.

14 Selody and Wilkins $(2010,30)$ define a systemic event as one that "creates a widespread shortage of liquidity that disrupts a wide range of institutions and markets, distorting asset prices more generally." This definition leaves room for interpretation and discretion. In the case of the last financial crisis, no special perspicacity was required to recognize the complete freezing up of the Canadian asset-backed commercial paper market as a systemic event. 
and preventing or mitigating solvency crises for systemically important financial institutions - have come to be known as macroprudential policy. The "macro" in macroprudential policy refers to the idea that financial stability policy deals with equilibrium in financial markets and how financial markets interact with the rest of the economy. The regulation of individual financial firms without regard to this interaction comes under the umbrella of microprudential policy.

Microprudential regulations typically are thought of as being invariant over time and across different individual firms. Macroprudential policies, in contrast, can have a time-variant component (related to the business cycle) and can vary across different firms - for example, when some firms are of sufficient importance to systemic consequences for financial market equilibrium and the macroeconomy. The toolkit for macroprudential policy includes tools to address excessive credit expansion (dynamic capital buffers, regulated loanto-value ratios, debt-service-to-income ratios and so on), tools to limit excessive leverage (risk weights, limits on intrafinancial sector exposures and so on) and tools to limit systemic spillovers (for example, measures of interconnectedness and of common risk exposures); for a comprehensive summary, see Financial Stability Board (2011).

Much of the literature on macroprudential regulation is not explicit about the fundamental sources of instability in financial markets or about the source of market failures and/or externalities that make regulation necessary. The 2007-08 financial crisis might have fostered the idea that financial markets (and capitalism in general) are inherently unstable, but, as Calomiris and Gorton (1991) argue, there are historical examples of stable financial markets, and institutional design does seem to matter. A clearer identification of potential market failures and their importance would help to focus the analysis. ${ }^{15}$ Examples include the following:

- market liquidity inherently involves a network externality (Buiter 2012);

- because of asymmetric information, financial markets are inherently prone to multiple equilibria and runs or panics (Gorton 2010);

- related to these information problems, external costs are associated with firms that attempt to divest themselves suddenly (fire sales) of assets they believe will lose their value (Hanson, Kashyap and Stein 2011);

- again because of asymmetric information, firms are limited in their borrowing by their perceived ability to repay their loans, and small shocks that affect their net worth can have strong feedback effects (Bernanke, Gertler and Gilchrist 1996);

- a decline in expectations concerning future revenues can lead to a crash in asset prices because of changes in equilibrium leverage and the bankruptcy of the most optimistic individuals (Geanakoplos 2009); and

- the moral hazard created by central banks' credit policy can itself lead to excessive risk-taking by financial firms that believe that the central bank will bail them out.

Bernanke $(2011,2)$ spells out the potential scope for macroprudential policy: "[B]ecause of the highly interconnected nature of our financial system, macroprudential oversight must be concerned with all major segments of the financial sector, including financial institutions, markets, and infrastructures; it must also place particular emphasis on understanding the complex linkages and interdependencies among institutions and markets, as these linkages determine how instability may be propagated throughout the system." This statement recognizes that macroprudential policy must be complex, but it understates the importance of this

15 Jeanne and Korinek (2016) explicitly model the interaction between macroprudential regulation and monetary policy in a model in which borrowing is constrained by the availability of collateral. 
complexity by implying that central banks are up to the task of understanding these complexities.

Currently, the Bank of Canada's main focus is on monetary policy, which entails bringing the inflation rate back to 2 percent within a period of eight quarters in most circumstances. Subject to many caveats about the choice of the inflation measure (see the next section) and the "flexible" part of flexible inflation targeting, which opens the door for the stabilization of fluctuations in real variables, this is a fairly clear and limited goal. In its role as inflation targeter, a central bank already has many requirements for the information it needs and the intellectual and computing power to process this information. ${ }^{16}$ However, the information required to tailor monetary policy so that it targets financial stability as well as inflation is an order of magnitude more complex. Assessing the systemic importance of individual institutions involves detailed knowledge of how equilibria are determined in financial markets and making judgments about the quantitative importance of the externalities imposed by systemically important institutions on that market equilibrium. This is precisely the "pretense of knowledge" problem Hayek ([1974] 1989) highlighted in his Nobel Prize address.

The financial crisis of 2007-08 had its proximate origins in a freezing up of the interbank market in the United States. It shared some common features with previous financial crises, but there were important structural differences as well, and the Bank of Canada should not ignore the important distinction between risk, on the one hand, and immeasurable uncertainty in the sense of Knight (1921), on the other. ${ }^{17}$ Assessing systemic risk involves the statistical analysis of many different disaggregated time series. If there are important structural differences from one financial crisis to the next, and if the next serious financial crisis originates in a market that so far has escaped the attention of risk analysts, it seems likely that the time series used to estimate risk will be too short for one to have any confidence in the results. As Kohn (2014 notes, "[i]n addition, systemic risks often involve the tails of distributions - vulnerabilities to unexpected developments." Financial time series are also known to deviate significantly from normal distributions, with "fat tails," a point argued forcefully by Taleb (2013), who claims that risk assessment is practically impossible even at the level of individual stocks and companies. ${ }^{18}$ These arguments suggest strongly that central banks, or any other analysts, might be unable to evaluate the importance of systemic risks with precision, and that simple heuristic policies should be used to analyze and deal with potential financial crises, as Haldane and Madouros (2012) suggest.

Unfortunately, recent proposals for combating financial crises seem to be headed in precisely the wrong direction. Haldane and Madouros (2012) note that the regulations for capital requirements for financial institutions are becoming increasingly complex, creating unintended consequences for banks' incentives to skew their holdings toward assets that require little offsetting capital holdings. They note that the Basel I accord defined five different risk weights and was 30 pages long; the Basel II agreement was longer by an order of magnitude -347 pages; while the Basel III agreement, at 616 pages, was almost double the length of the previous agreement.

16 For this reason, monetarists such as Friedman (1968) and Simons (1936) have suggested limiting monetary policy to the mechanical execution of simple rules.

17 Salter (2014) argues for the importance of uncertainty, as opposed to risk, in financial markets. Poloz (2014) also recognizes its importance.

18 Dowd (2014) also argues that risk assessment by the US Federal Reserve and other central banks is fundamentally inadequate because of tail risk. 


\section{Implications for the Bank of Canada}

Whether macroprudential regulation is based on simple heuristics or on complicated models of systemic risk, more regulation would entail more nonmarket control over the allocation of resources, as Salter (2014) stresses. As with credit policy, this, in turn, has distributional consequences. For this reason, macroprudential policy should be the responsibility of a separate body, not entrusted exclusively to the Bank of Canada. Because of its expertise, the Bank should be a member of such a body, but it should be chaired by the Department of Finance in recognition of the allocative and fiscal implications its policies would have, and hence the need for more direct accountability to the electorate. The body should focus on coming up with simple and robust heuristics to assess financial imbalances, while the Bank should use its overnight rate to achieve its monetary policy goals, not to affect financial stability. The independent body responsible for financial stability should use a different set of instruments than those the Bank uses to conduct monetary policy. The Bank should remain responsible for providing overall liquidity to the financial sector with allocations to specific institutions subject to market forces, and it should refine and make more precise the list of principles outlined above.

In a recent speech, Bank of Canada Governor Stephen Poloz (2015a) noted that different advanced economies have different governance models for macroprudential policy. In many cases, the mandate is centralized - sometimes within the central bank, as is the case at the Bank of England, or outside the central bank, as in the United States. Some macroprudential bodies have the power to write regulations; others are limited to monitoring and making recommendations. Poloz stated that "it's crucial that central banks be involved," with which I would concur, but was otherwise agnostic as to which model is suitable. The implications of credit policy for the Bank's accountability and independence, however, argue strongly in favour of not centralizing the mandate within the Bank. ${ }^{19}$

\section{The Bottom Line}

Concerning Buiter's (2012) second and third roles for financial stability policy, the Bank of Canada should refine and extend its guidelines for extending liquidity to financial markets. In particular, following Tucker (2015), it should consider under what limited circumstances it would extend credit bilaterally to individual financial institutions while still favouring a market-based allocation mechanism. It should also consider if and under what circumstances it would intervene in frozen markets for particular asset classes by acting as market maker of last resort. Concerning Buiter's first and fourth roles, and acknowledging the inherent limitations of assessments of misalignment in financial markets and systemic risks, macroprudential policy should concentrate on simple heuristic strategies based on the principle of "skin in the game." To the extent that macroprudential policy involves nonmarket control over the allocation of resources, it would be better for the Bank to participate as one of several experts in an independent body tasked to promote financial stability. Otherwise, it would leave itself open to criticism for a lack of accountability and thereby risk jeopardizing its operational independence. The independent body should be directly responsible to the Department of Finance. ${ }^{20}$

19 Kohn (2014) compares the UK model, in which the mandate is centralized with the Bank of England, and the US model, where a separate body has been set up, and concludes in favour of the latter.

20 There is broad consensus in previous work published by the C.D. Howe Institute that the Bank should not be given sole and full responsibility for financial stability; see, for example, Crowe (2012); Jenkins and Longworth (2015); Jenkins and Thiessen (2012); and Ragan (2012). 


\section{THE MEASUREMENT AND RELEVANCE OF CORE INFLATION}

The current inflation-targeting regime obliges the Bank of Canada to bring headline (CPI) inflation back to the 2 percent target within a period of eight quarters. The CPI contains many components that are quite volatile and subject to idiosyncratic shocks. For this reason, many central banks, including Canada's, look at some measure of "core" inflation that strips out the volatile components when formulating their monetary policy. Côté $(2014,7)$ notes that an "effective core measure must have four key properties. It must be less volatile than total inflation; track long-run movements in the total CPI very closely (in other words, be 'unbiased'); reliably predict future trend movements in the total CPI; and be easy to understand and explain to the public."The Bank currently uses the CPIX index as its preferred core price index. ${ }^{21}$ The CPIX excludes eight of the most volatile components of the CPI (fruit, vegetables, gasoline, fuel oil, natural gas, intercity transportation, tobacco and mortgage interest costs), adjusting the remainder for the effect of changes in indirect taxes. As for reliably predicting future trend movements in the total CPI, the Bank needs to outline in more detail what uses it will make in practice of a core inflation indicator.

\section{Core Inflation as a Predictor of Headline Inflation}

First and foremost, if the Bank of Canada were to use core inflation as an indicator when setting the overnight rate to target headline inflation, then core - or any other indicator, for that matter - should be a poor predictor of inflation at times close to the Bank's self-imposed eight-quarter period for bringing inflation back to target. In fact, the best predictor of inflation eight quarters ahead should be the target rate itself. There is a fairly long line of research, including research at the Bank itself, that demonstrates this result - see, for example, Clinton (2006); Otto and Voss (2014); and Rowe and Yetman (2002).

The argument is simple. The Bank of Canada uses all information currently available (including core inflation), plus its model of the Canadian economy, to set its policy rate. The interest rate is set so that, in the absence of unexpected shocks, inflation will return to its target within the eightquarter limit. If information available to the Bank helps to predict the deviation of inflation from its target eight quarters later, the Bank will not have set its policy rate optimally. ${ }^{22}$ If the Bank were to use that additional information when formulating the policy rate, that would be enough to eliminate the conditional correlation between realized deviations of inflation from the target and information available to the Bank when it formulates its policy. Core inflation, in contrast, could help as a predictor of future inflation only at horizons much shorter than the Bank's eight-quarter limit. Even at shorter horizons, however, if the Bank's policy closed the gap between current headline inflation and the target rate in a monotonic fashion, the current gap should be close to the best predictor of inflation. ${ }^{23}$

\section{Core Inflation as a Target}

Theoretical research also suggests using some measure of core inflation as the actual target, rather

21 For a survey of different possible measures of core inflation, see Khan, Morel and Sabourin (2015).

22 The Bank's policy rate is optimal within the context of its main forecasting and policy analysis tool, ToTEM. If information outside the model helps to predict inflation, this would suggest dimensions along which ToTEM should be modified to improve its performance.

23 Poschmann and Jacobs (2015) show that an index generated as the principal component of 167 sub-indices of the CPI forecasts the overall CPI well at horizons out to between six and eighteen months. 
than just as an indicator of the direction in which inflation is heading in the short run. It would be beneficial, therefore, to replace headline inflation with some measure of inflation similar to core as the actual target. Targeting an appropriate price index other than the overall CPI could lead to improvements in economic welfare. ${ }^{24}$

If the CPI contained some components that are more sticky, economic welfare could be enhanced by stabilizing those components and allowing the more flexible components - which are inherently closer to their welfare-maximizing flexible-price values - to adjust by themselves. This would mean targeting an index with components weighted by their degree of stickiness. Note that, as long as these components move in trend with the CPI, the CPI itself would increase on average at the same rate as the targeted index: the distributional consequences and loss of credibility associated with a change in the targeted rate of inflation would not apply.

These are more than just theoretical results. It is relatively straightforward to calculate a price index adjusted for the degree of stickiness of its components. The Federal Reserve Bank of Atlanta already does so, and publishes its data on the same day as the release of the official CPI statistics. Bryan and Meyer (2010) explain the methodology used: the degree of stickiness depends on the average frequency of price adjustment in a given sector. The authors also show that stickier prices are more forward-looking than flexible prices, helping to forecast inflation at very short horizons. Finally, they find the flexible-price CPI to be more sensitive to measures of economic slack than is headline inflation.

One strong implication of the theoretical literature is that it would be optimal for a central bank to stabilize all prices to the extent that they are sticky. Monetary policy can provide a stable and predictable price level, and it can also help move prices toward what they would be if they could adjust freely. It would be better to stabilize prices that are slow to adjust, and allow prices that adjust quickly by themselves to do so. As Erceg, Henderson and Levin (2000) show, this extends to wages if they are sticky. ${ }^{25}$ An appropriate target to maximize economic welfare should include a combination of prices and wages, weighted by relative stickiness, and adjusting targeted wage growth for productivity gains. ${ }^{26}$ The target growth rate for the appropriate goods price index could still be 2 percent. ${ }^{27}$ Using such an index, however, would pose a communications challenge for the Bank: the Bank currently reports the value of core inflation; it could follow the lead of the Federal Reserve Bank of Atlanta by providing on its website the necessary data and methodology for computing a modified index.

\section{Core Inflation and Level Targeting}

I suggested earlier that level targeting must be symmetric to be credible and, therefore, effective. In addition to correcting the effects of negative

24 For the relevant theoretical arguments, see, for example, Aoki (2001); Dhawan and Jeske (2007); and Erceg, Henderson and Levin (2000).

25 De Resende, Dib and Kichian (2010) compare the benefits of targeting headline inflation versus targeting individual components of the overall price index, and find that targeting headline inflation does as well or better. However, they do not look at an index with weights on components that depend on the degree of stickiness or at one that incorporates wages, even though their model includes nominal wage rigidity.

26 Because of trend productivity gains, real wages in the Canadian economy trend upwards, implying that average nominal wages and the price level diverge over time.

27 The appropriate weights to put on wage stability versus price stability would have to be determined within the context of a model such as the Bank of Canada's ToTEM model. 
shocks to inflation on the price level, a central bank must also correct the effects of positive shocks on the price level. A common objection to pricelevel targeting is that the central bank would face substantial political resistance if it were obliged to engineer a substantial reduction in inflation in response to a strong positive energy price shock. The literature concerning the choice of the appropriate price index to target puts a very low weight on energy prices or excludes them altogether, because - especially for a small, open economy such as Canada's - energy prices are determined on world markets, and are not subject to influence by a central bank. Barring persistent shocks to the relative prices of energy and other commodities, the average rate of inflation of the targeted index would track overall CPI inflation. By targeting the appropriate index, the central bank would not have to restrict aggregate demand and, in extreme cases, engineer a recession to bring the price index back on track. On the other hand, positive inflation shocks due to aggregate demand shocks would lead the central bank to offset them using monetary policy, and level targeting could lead to greater stability of both inflation and output. ${ }^{28}$

\section{The Bottom Line}

The search for a measure of core inflation with high predictive power is somewhat misplaced. If core inflation were one of the indicators the Bank of Canada used when setting the overnight rate, then after-the-fact core inflation should have very little predictive power for headline inflation in the Bank's self-imposed period for bringing headline inflation back to target if the Bank is doing its job well.
Strong arguments exist for actually targeting a corelike measure of inflation in which components of the index are weighted by their degree of stickiness. Targeting such an index could lead to increased economic welfare by making monetary policy more effective, even if it is overall headline inflation that is costly to households. Although it might not be feasible to coordinate on such an index in time for the 2016 agreement, the Bank should prepare to move to target a different index in the medium term.

\section{CONCLUSION}

The policy recommendations that follow from this analysis are relatively simple. In renewing its agreement with the federal government concerning the inflation-control target, the Bank of Canada should

- set the bar high for any increase in the target;

- consider modifications to the monetary policy framework up to and including level targeting;

- refine and expand its guidelines for liquidity provision in times of crisis;

- seek simple heuristic approaches to promote financial stability;

- continue to mitigate risks of moral hazard;

- refrain from taking on direct responsibilities vis-à-vis financial stability that have significant allocative or distributional consequences;

- reserve the overnight rate to target its monetary policy objectives; and

- consider targeting a price index that strips out volatile and nonsticky components, rather than using such an index just to predict movements of overall headline inflation.

28 Ambler $(2009,2014)$ details how price-level targeting could lead to increased inflation and output stability in response to demand shocks. 


\section{REFERENCES}

Amano, Robert, and Steve Ambler. 2014. "Price-Level

Targeting and the Zero Lower Bound." Bank of

Canada and Université du Québec à Montréal.

Unpublished.

Amano, Robert, James Engel-Warnick, and Malik

Shukayev. 2011. "Price-Level Targeting and

Inflation Expectations: Experimental Evidence.”

Working Paper 2011-18. Ottawa: Bank of Canada.

Amano, Robert, and Malik Shukayev. 2010. "Monetary

Policy and the Zero Bound on Nominal Interest

Rates." Bank of Canada Revierw (Summer): 3-10.

\section{Zero Bound on Nominal Interest Rates." Journal of}

Money, Credit and Banking 44 (8): 1475-1505.

Ambler, Steve. 2008. “The Costs of Inflation in New

Keynesian Models." Bank of Canada Review

(Winter): 5-14.

_.2009. "Price-Level Targeting and Stabilization Policy: A Survey." Journal of Economic Surveys 23, 974-997

_- 2014. Price-Level Targeting: A Post Mortem? Commentary 400. Toronto: C.D. Howe Institute.

Ambler, Steve, and Craig Alexander. 2015. “One

Percent? For Real? Insights from Modern Growth

Theory about Future Investment Returns.” E-Brief

216. Toronto: C.D. Howe Institute.

Ambler, Steve, and Jean-Paul Lam. 2015. "Price-Level

Targeting, Inflation Targeting and Indeterminacy."

Université du Québec à Montréal. Unpublished.

Aoki, Kosuke. 2001. "Optimal Monetary Policy

Responses to Relative-Price Changes." Journal of

Monetary Economics 48 (1): 55-80.

Ascari, Guido, Louis Phaneuf, and Eric Sims. 2015. “On the Welfare and Cyclical Implications of Moderate Trend Inflation."Working Paper 21392. Cambridge, MA: National Bureau of Economic Research.

Bagehot, Walter. [1873] 1999. Lombard Street: A Description of the Money Market. Reprinted New York: Wiley \& Sons.
Bank of Canada. 2011. "Renewal of the Inflation-

Control Target: Background Information -

November 2011.” Ottawa.

Bayoumi, Tamim, Giovanni Dell'Ariccia, Karl

Habermeier, Tommaso Mancini-Griffoli, and

Fabián Valencia. 2014. "Monetary Policy in the New

Normal.” Staff Discussion Note 14-3. Washington,

DC: International Monetary Fund.

Benhabib, Jess, Stephanie Schmitt-Grohé, and Martín

Uribe. 2001a. "Monetary Policy and Multiple

Equilibria." American Economic Review 91 (1): 167-86.

. 2001b. "The Perils of Taylor Rules."

Journal of Economic Theory 96 (1-2): 40-69.

Berg, Claes, and Lars Jonung. 1999. "Pioneering Price

Level Targeting: The Swedish Experience 1931-

1937." Journal of Monetary Economics 43 (3): 525-51.

Bernanke, Ben. 2011. "Implementing a Macroprudential Approach to Supervision and Regulation." Speech given at the Forty-Seventh Annual Conference on Bank Structure and Competition, Chicago, May 5. Available online at http://www.federalreserve.gov/ newsevents/speech/bernanke20110505a.htm.

Bernanke, Ben, Mark Gertler, and Simon Gilchrist. 1996. "The Financial Accelerator and the Flight to Quality." Review of Economics and Statistics 78 (1): $1-15$.

Blanchard, Olivier, Giovanni Dell'Ariccia, and Paolo Mauro. 2010. "Rethinking Macroeconomic Policy." Journal of Money, Credit and Banking 42 (suppl.): 199-215.

Bordo, Michael. 2014. "Rules for a Lender of Last Resort: An Historical Perspective." Journal of Economic Dynamics and Control 49: 126-34.

Bryan, Michael, and Brent Meyer. 2010. "Are Some Prices in the CPI More Forward Looking than Others? We Think So." Economic Commentary 2010-2. Atlanta: Federal Reserve Bank of Atlanta. 
Buiter, Willem. 2012. "The Role of Central Banks in Financial Stability: How Has It Changed?” Discussion Paper 8780. London: Centre for Economic Policy Research.

Bullard, Charles. 2010. "The Seven Dimensions of 'The Peril'." Federal Reserve Bank of St. Louis Review, September-October, 339-52.

Calomiris, Charles, and Gary Gorton. 1991. "The Origins of Banking Panics: Models, Facts, and Bank Regulation." In Financial Markets and Financial Crises, ed. R.G. Hubbard, 109-74. Chicago: University of Chicago Press.

Clinton, Kevin. 2006. "Core Inflation at the Bank of Canada: A Critique.”Working Paper 1077. Kingston, ON: Queen's University, Department of Economics.

Cochrane, John. 2009. "Lessons from the Financial Crisis." Regulation 32 (4): 34-7.

Coibion, Olivier, Yuriy Gorodnichenko, and Johannes Wieland. 2012."The Optimal Inflation Rate in New Keynesian Models: Should Central Banks Raise Their Inflation Targets in Light of the Zero Lower Bound?" Review of Economic Studies 79 (4): 1371-1406.

Côté, Agathe. 2014. "Inflation Targeting in the PostCrisis Era." Remarks to the Calgary CFA Society, November 18. Available online at http://www. bankofcanada.ca/2014/11/inflation-targeting-postcrisis-era/.

Crow, John. 2012. Seeking Financial Stability: The Best Role for the Bank of Canada. Commentary 369. Toronto, C.D. Howe Institute.

Dennis, Richard. 2003. “Time-Inconsistent Monetary Policies: Recent Research.” Economic Letter 200310. San Francisco: Federal Reserve Bank of San Francisco.

Dennis, Richard, and Ulf Söderström. 2006. "How Important Is Precommitment for Monetary Policy?” Journal of Money, Credit and Banking 38 (4): 847-72.

De Resende, Carlos, Ali Dib, and Maral Kichian. 2010. "Alternative Optimized Monetary Policy Rules in Multi-Sector Small Open Economies: The Role of Real Rigidities."Working Paper 2010-9. Ottawa: Bank of Canada.
Dhawan, Rajeev, and Karsten Jeske. 2007. "Taylor Rules with Headline Inflation: A Bad Idea.”Working Paper 2007-14. Atlanta: Federal Reserve Bank of Atlanta.

Dowd, Kevin. 2014. "Math Gone Mad: Regulatory Risk Modeling by the Federal Reserve." Policy Analysis 754. Washington, DC: Cato Institute. Available online at http://www.cato.org/publications/policyanalysis/math-gone-mad

Engert, Walter, Jack Selody, and Carolyn Wilkins. 2008. "Financial Market Turmoil and Central Bank Intervention.” Financial System Review (June): 71-8.

Erceg, Christopher, David Henderson, and Andrew Levin. 2000. "Optimal Monetary Policy with Staggered Wage and Price Contracts." Journal of Monetary Economics 46 (2): 281-313.

Evans, George, Eran Guse, and Seppo Honkapohja. 2008. "Liquidity Traps, Learning and Stagnation." European Economic Review 52 (8): 1438-63.

Financial Stability Board. 2011. "Macroprudential Policy Tools and Frameworks: Progress Report to G20." Basel, Switzerland. Available online at http://www. bis.org/publ/othp17.htm.

Friedman, Milton. 1968. "The Role of Monetary Policy." American Economic Review 58 (1): 1-17.

Geanakoplos, John. 2009. “The Leverage Cycle.” In NBER Macroeconomic Annual, Volume 24, ed. Daron Acemoglu, Kenneth Rogoff, and Michael Woodford, 1-65. Chicago: University of Chicago Press.

Goodfriend, Marvin. 2014. "Lessons from a Century of Fed Policy: Why Monetary and Credit Policies Need Rules and Boundaries." Journal of Economic Dynamics and Control 49 (C): 112-20.

Gorton, Gary. 2010. Slapped in the Face by the Invisible Hand. Oxford: Oxford University Press.

Haldane, Andrew, and Vasileios Madouros. 2012. "The Dog and the Frisbee." Remarks at the Federal Reserve Bank of Kansas City's 36th economic policy symposium, "The Changing Policy Landscape," Jackson Hole, WY, August 31. 
Haltom, Renee, and Jeffrey Lacker. 2014a. "Should the Fed Do Emergency Lending?” Economic Brief 14-07. Richmond, VA: Federal Reserve Bank of Richmond.

. 2014b. "Should the Fed Have a Financial Stability Mandate? Lessons from the Fed's First 100 Years." Federal Reserve Bank of Richmond Economic Quarterly 101 (1): 4-25. Available online at http:// www.richmondfed.org/publications/research/ annual_report/ 2014/ar2014.

Hanson, Samuel, Anil Kashyap, and Jeremy Stein. 2011. "A Macroprudential Approach to Financial Regulation." Journal of Economic Perspectives 25 (1): 3-28.

Hayek, Friedrich. [1974] 1989. “The Pretence of Knowledge.” American Economic Review 79 (4): 3-7.

Hogan, Thomas, Linh Le, and Alexander Salter. 2015. "Ben Bernanke and Bagehot's Rules." Journal of Money, Credit and Banking 47 (2-3): 333-48.

Hummel, Jeffrey. 2011. "Ben Bernanke versus Milton Friedman: The Federal Reserve's Emergence as the U.S. Economy's Central Planner." Independent Review 15 (4): 485-518.

Humphrey, Thomas. 1989. "Lender of Last Resort: The Concept in History.” Economic Review (Federal Reserve Bank of Richmond) 75 (March-April): 8-16. 2010. "Lender of Last Resort: What It Is, Whence It Came, and Why the Fed Isn't It." Cato Journal 30 (2): 333-64.

Jeanne, Olivier, and Anton Korinek. 2016. "Macroprudential Regulation versus Mopping Up after the Crash.”Johns Hopkins University. Unpublished.

Jenkins, Paul, and David Longworth. 2015. Securing Monetary and Financial Stability: Why Canada Needs a Macroprudential Policy Framework. Commentary 429. Toronto: C.D. Howe Institute.

Jenkins, Paul, and Gordon Thiessen. 2012. Reducing the Potential for Future Financial Crises: A Framework for Macro-Prudential Policy in Canada. Commentary 351. Toronto: C.D. Howe Institute.
Khan, Mikael, Louis Morel, and Patrick Sabourin. 2015. "A Comprehensive Evaluation of Measures of Core Inflation for Canada.” Discussion Paper 2015-12. Ottawa: Bank of Canada.

Knight, Frank. 1921. Risk, Uncertainty, and Profit. Boston: Hart, Schaffner \& Marx.

Kohn, Donald. 2014. "Institutions for Macroprudential Regulation: The UK and the U.S." Speech to the Brookings Institution, Washington, DC, April 17. Available online at http://www.brookings. edu/research/speeches/2014/04/17-institutionsmacroprudential-regulation-kohn.

Kozicki, Sharon, Eric Santor, and Lena Suchanek. 2011. "Unconventional Monetary Policy: The International Experience with Central Bank Asset Purchases." Bank of Canada Review (Spring): 13-25.

Kryvtsov, Oleksiy, and Rhys Mendes. 2015. "The Optimal Level of the Inflation Target: A Selective Review of the Literature and Outstanding Issues.” Discussion Paper 2015-8. Ottawa: Bank of Canada.

Kydland, Finn, and Edward Prescott. 1977. "Rules Rather than Discretion: The Inconsistency of Optimal Plans." Journal of Political Economy 85 (3): 473-91.

Laidler, David. 2003. "Two Views of the Lender of Last Resort: Thornton and Bagehot." Cabiers d'économie politique / Papers in Political Economy 45: 61-78.

Longworth, David. 2010. "Bank of Canada Liquidity Facilities: Past, Present and Future.” Remarks at the C.D. Howe Institute, Toronto, February 17. Available online at http://www.bankofcanada. ca/2010/02/liquidity-facilities-past-present-future/.

Macklem, Tiff. 2014. "Flexible Inflation Targeting and 'Good' and 'Bad' Disinflation." Remarks at the John Molson School of Business, Concordia University, Montreal, February 7. Available online at http:// www.bankofcanada.ca/2014/02/flexible-inflationtargeting-good-bad-disinflation/.

Mehrling, Perry. 2011. The Nerw Lombard Street: How the Fed Became the Dealer of Last Resort. Princeton, NJ: Princeton University Press. 2014. "Why Central Banking Should Be Re-Imagined.” BIS Paper 79. Basel, Switzerland: Bank for International Settlements. 
Nessén, Marianne, and David Vestin. 2005. "Average Inflation Targeting." Journal of Money, Credit and Banking 37 (5): 837-63.

Otto, Glenn, and Graham Voss. 2014. "Flexible Inflation Forecast Targeting: Evidence from Canada." Canadian Journal of Economics 47 (2): 398-421.

Poloz, Stephen. 2014. “Integrating Uncertainty and Monetary Policy-Making: A Practitioner's Perspective.” Discussion Paper 2014-6. Ottawa: Bank of Canada.

—_. 2015a. "Integrating Financial Stability into Monetary Policy.” Remarks to the National Association for Business Economics, Washington, DC, October 12. Available online at http://www. bankofcanada.ca/2015/10/integrating-financialstability-into-monetary-policy/.

\section{. 2015b. "Prudent Preparation: The} Evolution of Unconventional Monetary Policies." Remarks at the Empire Club of Canada, Toronto, December 8. Available online at http://www. bankofcanada.ca/2015/12/prudent-preparationevolution-unconventional-monetary-policies/.

Poschmann, Finn, and Aaron Jacobs. 2014. "Improving on the CPI: A Proposal for a Better Inflation Indicator.” E-Brief 213. Toronto: C.D. Howe Institute.

Ragan, Christopher. 2012. Financial Stability: The Next Frontier for Canadian Monetary Policy. Commentary 338. Toronto: C.D. Howe Institute.

Roberts, Russell. 2010. “Gambling with Other People's Money: How Perverted Incentives Caused the Financial Crisis.” Arlington, VA: George Mason University, Mercatus Center.
Rowe, Nicholas, and James Yetman. 2002. "Identifying a Policymaker's Target: An Application to the Bank of Canada." Canadian Journal of Economics 35 (2): 239-56.

Salter, Alexander. 2014. "The Imprudence of Macroprudential Policy." Independent Review 19 (1): 5-17.

Santor, Eric, and Lena Suchanek. 2013. "Unconventional Monetary Policies: Evolving Practices, Their Effects and Potential Costs." Bank of Canada Review (Spring): 1-15.

Selody, Jack, and Carolyn Wilkins. 2010. “The Bank of Canada's Extraordinary Liquidity Policies and Moral Hazard." Financial System Review (June): 29-32.

Simons, Henry. 1936. "Rules versus Authorities in Monetary Policy." Journal of Political Economy 44 (1): 1-30.

Taleb, Nassim. 2013. "What We Learn from Firefighters: How Fat Are the Tails?” edge.org. Available online at http://edge.org/responsedetail/23839; accessed November 30, 2015.

Tucker, Paul. 2015. “The Lender of Last Resort and Modern Central Banking: Principles and Reconstruction.” BIS Papers 79. Basel, Switzerland: Bank for International Settlements.

White, Lawrence. 2010. "The Rule of Law or the Rule of Central Bankers?” Cato Journal 30 (3): 451-63.

Wilkins, Carolyn. 2014. "Monetary Policy and the Underwhelming Recovery." Remarks to the CFA Society, Toronto, September 22. Available online at http://www.bankofcanada.ca/2014/09/monetarypolicy-underwhelming-recovery. 


\section{ReCEnt C.D. Howe Institute Publications}

May 2016

May 2016

May 2016

May 2016

May 2016

April 2016

April 2016

April 2016

April 2016

March 2016

March 2016

March 2016

March 2016

Boadway, Robin, and Jean-François Tremblay. Modernizing Business Taxation. C.D. Howe Institute Commentary 452.

Schwanen, Daniel, and Benjamin Dachis. Changing the Channel on Canadian Communications Regulation. C.D. Howe Institute Commentary 451.

Gray, David, and Colin Busby. Unequal Access: Making Sense of EI Eligibility Rules and How to Improve Them. C.D. Howe Institute Commentary 450.

Pierlot, James, and Barry Gros. "DC Plans and the ORPP: Why Fees Matter." C.D. Howe Institute E-Brief.

Robson, William B.P., and Alexandre Laurin. Worse Than It Looks:The True Burden and Risks of Federal Employee Pension Plans. C.D. Howe Institute Commentary 449.

Ciuriak, Dan, Ali Dadkhah, and Jingliang Xiao. "Better In than Out? Canada and the Trans-Pacific Partnership.” C.D. Howe Institute E-Brief.

Sen, Anindya. "Joint Venture: A Blueprint for Federal and Provincial Marijuana Policy." C.D. Howe Institute E-Brief.

Busby, Colin, and Robson, William B.P. Controlling the Public Purse: The Fiscal Accountability of Canada's Senior Governments, 2016. C.D. Howe Institute Commentary 448.

Klassen, Ken. "Auditing the Auditors: Tax Auditors Assessments and Incentives.” C.D. Howe Institute E-Brief.

Parkin, Michael. “Mounting Evidence: Findings from Natural Experiments in Inflation Targeting." C.D. Howe Institute E-Brief.

Found, Adam. "Tapping the Land: Tax Increment Financing of Infrastructure." C.D. Howe Institute E-Brief.

Robson, William B.P., and Alexandre Laurin. Where the Bucks Stop: A Shadow Federal Budget for 2016. C.D. Howe Institute Commentary 447.

Beine, Michel, Robin W. Boadway, and Serge Coulombe. Moving Parts: Immigration Policy, Internal Migration and Natural Resource Shocks. C.D. Howe Institute Commentary 446.

\section{SUPPORT THE INSTITUTE}

For more information on supporting the C.D. Howe Institute's vital policy work, through charitable giving or membership, please go to www.cdhowe.org or call 416-865-1904. Learn more about the Institute's activities and how to make a donation at the same time. You will receive a tax receipt for your gift.

\section{A REPUTATION FOR INDEPENDENT, NONPARTISAN RESEARCH}

The C.D. Howe Institute's reputation for independent, reasoned and relevant public policy research of the highest quality is its chief asset, and underpins the credibility and effectiveness of its work. Independence and nonpartisanship are core Institute values that inform its approach to research, guide the actions of its professional staff and limit the types of financial contributions that the Institute will accept.

For our full Independence and Nonpartisanship Policy go to www.cdhowe.org. 

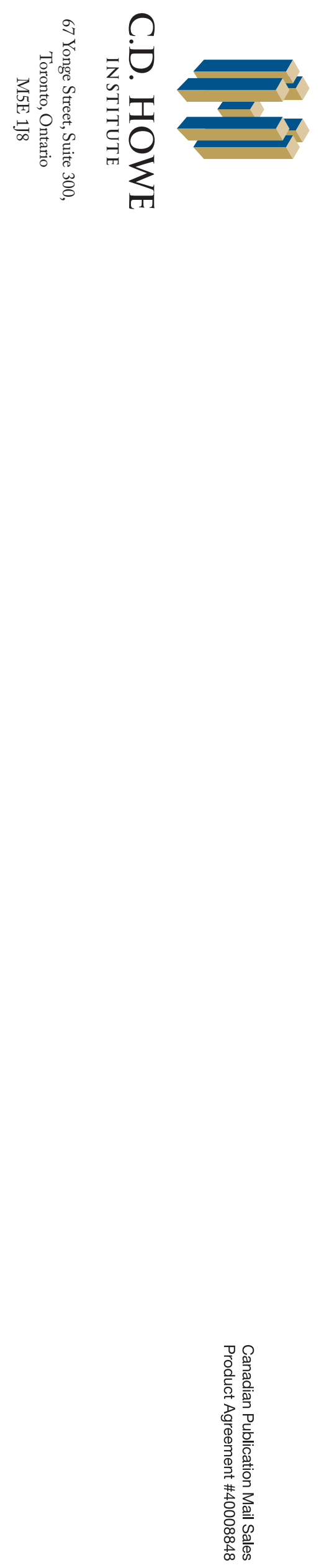